\title{
Pozytywistyczny poemat humorystyczny
}

Tadeusz Budrewicz 
NAPIS Seria XIV 2008

\section{Tadeusz Budrewicz}

\section{Pozytywistyczny poemat humorystyczny}

$\mathrm{O}$

d Piotra Chmielowskiego począwszy, wszystkie syntezy literatury pozytywizmu wysoko cenią prozatorską humorystykę epoki, uznając za klasyków Bolesława Prusa i Jana Lama, rzadziej wspominając Kazimierza Bartoszewicza. Znacznie niżej w hierarchii osiągnięć artystycznych lokuje się poetów-humorystów czy satyryków. Tu zwykle ogranicza się do Chochlika (Włodzimierza Zagórskiego) i Rodocia (Mikołaja Biernackiego). Kanon nazwisk jest więc stabilny. Zwraca uwagę fakt, iż na tej liście znajduje się tylko jeden przedstawiciel centrum literacko-artystycznego tego okresu, czyli Warszawy. Gros nazwisk reprezentuje Lwów. To kolejna niekwestionowana teza: w Kongresówce, z powodów politycznych, było strasznie, a w Galicji - śmiesznie. Z kolei w Galicji stańczykowsko-konserwatywno-bigoteryjny Kraków nie miał zrozumienia dla humoru, w przeciwieństwie do liberalno-mieszczańsko-demokratycznego Lwowa. Nawiązując do współczesnego określenia „zielonogórskie zagłębie kabaretowe", można powiedzieć, iż w drugiej połowie XIX wieku istniało lwowskie zagłębie satyryczno-humorystyczne. Taka teza znajduje potwierdzenie w stanie badań nad satyrą polską okresu pozytywizmu ${ }^{1}$. Znamienne, że najwybitniejsi autorzy do dziś nie doczekali się monografii oraz że los pisarzy podzielają ówczesne czasopisma humory-

\footnotetext{
${ }^{1}$ Zob. S. Frybes, W krainie groteski. Problemy satyry galicyjskiej drugiej połou'y XIX wieku, Wrocław-Gdańsk 1979; E. Skorupa, Lwowska satyra polityczna na tamach czasopism humorystyczno-satyrycznych epoki pozytywizmu, Kraków 1992; J. Korfel, Włodzimierz Zagórski. Portret biograficzno-literacki, Kraków 2000; T. Krzyżewski, Weterani hwowskiego czasopiśmiennictwa humorystycznego ( $Z$ dziejów polskiej prasy $w$ Galigi 1843-1918), „Rocznik Historii Czasopiśmiennictwa Polskiego” t. 15: 1976, z. 2, s. 171-205; E. Skorupa, „Znamiona zbrodni”. Cenzura i o cenzurze na tamach hwowskiego „Szczutka” i krakowskiego „Diabła”, w: Piśmiennictwo - systemy kontroli - obiegi alternatywne, red. J. Kostecki, A. Brodzka, Warszawa 1992, s. $328-354$.
} 
styczne, choć niektóre miały wysokie nakłady i dużą siłę opiniotwórczą. Można rzec, iż we wszystkich większych miastach wszystkich zaborów (nie tylko Galicji) wystąpiła wręcz „klęska urodzaju”, prawdziwy „wysyp” humorystycznych czasopism, pisemek, kalendarzy, noworoczników i jednodniówek. Tymczasem Kazimierz Bartoszewicz, penetrując dorobek polskiej humorystyki, stwierdzał:

Gdyby ułożyć spis bibliograficzny utworów humorystycznych z kilkudziesięciu lat ostatnich, to nawet pomijając rzeczy słabe, pomieścić by go można zaledwie na kilku arkuszach druku².

Nawet jeśli się przyjmie stanowisko Chmielowskiego, który wyraźnie lekceważył czasopisma humorystyczne ${ }^{3}$ i pouczal, że tworzone w ferworze bieżących polemik utwory „starzeją się” szybko, „stają się niezrozumiałe bez objaśnienia lub też wyglądają dla późniejszych pokoleń karykaturalnie"4, to i tak problemu humoru jako istotnej, a niedostatecznie opisanej, sygnatury epoki pozytywizmu nie można lekceważyć. To wtedy powstały wielotomowe antologie, zbierające teksty historyczne i współczesne: Ksiegi humoru polskiego ${ }^{5}$ oraz „encyklopedie humoru” ${ }^{\circ}$. Chmielowski, konsekwentny w metodzie biograficznej, znalazł wygodny argument, by tego działu piśmiennictwa nie omawiać:

Charakterystykę innych naszych satyryków, wypełniających łamy pism humorystycznych, trudno podać, gdyż indywidualność ich zakrywa się często rozmaitymi pseudonimami ${ }^{7}$.

To istotnie znak rozpoznawczy czasu - mnogość pseudo- i kryptonimów, czasem po prostu koniecznych, aby ukryć przed czytelnikiem, że dany numer pisma był $\mathrm{w}$ dużym stopniu dziełem tego samego autora (praktyka nierzadka $\mathrm{i} w$ pismach dla dzieci, jak wiemy z korespondencji Wladysława Bełzy z Józefem Ignacym Kraszewskim). Wyliczmy tu najpopularniejszych poetów - humorystów epoki pozytywizmu wraz z używanymi przez nich pseudonimami, pod którymi byli bardziej znani, ograniczając się tylko do twórców, których teksty przedrukowywano w encyklope-

${ }^{2}$ K. Bartoszewicz, Wstęp w: Ksiegi humoru polskiego, zebral K. Bartoszewicz, t. 4, Petersburg 1897, s. 7.

3 Oceniając "dłuższy poemacik satyryczny” Włodzimierza Zagórskiego Poradnik dla konkurentów, wyrokowal: „nie warto było uwieczniać tego utworu w formie książkowej; niechby sobie spoczywał w numerach któregoś z pism «humorystycznych», gdzie zapewne pierwotnie był pomieszczony [...]"

- P. Chmielowski, Wspótcześni poeci polscy. Szkice, Petersburg 1895, s. 266.

${ }^{4}$ Ibidem, s. 265.

${ }^{5}$ Zob. Ksiegi humoru polskiego, zebrał K. Bartoszewicz, t. 1-4, op. cit.

6 Zob. Encyklopedia humoru zawierająca najcelniejsze utwory humoru ludzkiego, red. M. Wołowski, t. 1, Warszawa 1889; Encyklopedia humoru i satyry polskiej, red. A. Ostrowski, t. 1-4, Warszawa 1914.

7 P. Chmielowski, Zarys najnowszej literatury polskiej (1864-1897), Kraków-Petersburg 1898, s. 357. 
diach humoru: Kazimierz Bartoszewicz (C. Hr. Zan, C. Hr. Ypka); Mikołaj Biernacki (Rodoć); Władysław Buchner (Ner-buch); Stanisław Dydyński (Asmodeusz, Es-de); Mieczysław Dzikowski (Iskra); Artur Glisczyński (Arg); Wiktor Gomulicki (Fantazy); Czesław Jankowski (Czesław); Maria Kamińska (Em-ka); Wincenty Kosiakiewicz (B. Młodywół); Paweł Kośmiński (Almanzor, Paul de Coś, Saltomortale); Konstanty Krumłowski (Chat-Noire); Kazimierz Laskowski (El); Bolesław Londyński (Bruno Las); Aleksander Messyng (Almess, Gwynplaine); Artur Oppman (Or-ot, Gnom, Szpilka); Antoni Orłowski (F-o, Fortunio, K-c, Krogulec, Puszczyk); Franciszek Reinstein (Francesco, F. R-n, Fulgenty, Hidalgo); Władysław Sabowski (Aureli Kurcz, Wołody Skiba); Julian Starkel (Nie-Dante); Włodzimierz Stebelski (Aleksander Dym, Fidybus, Mgła, Roman Zero); Faustyn Świderski (ExBocian); Józef Waśniewski (Duduś); Włodzimierz Zagórski (Chochlik); Stanisław Żyżkowski (Esżet)... To tylko część piszących i publikujących. Można tę listę wydłużać o autorów publikujących przynajmniej lat kilkanaście, jak na przykład Maczuga (Edward Łoziński), zapełniający lamy „Diabła”, czy również tu drukujący pod pseudonimem „Em. Nelin” Emanuel Goździewicz - ale sporządzenie kompletnego zestawienia jest po prostu niemożliwe. Dla wielu piszących satyryków ujawnienie nazwiska oznaczałoby kłopoty zawodowe i towarzyskie, niektórym zdolności rymotwórczych wystarczyło na kilka wierszyków, więc zamilkli. O zdefektowanych, przetrzebionych, zniszczonych itp. zbiorach czasopism satyrycznych można napisać tomy elegii i lamentów. Uwarunkowania zewnętrzne (niewielkie rozmiary periodyków, wydawnictwa okolicznościowe, nieregularne) i uzależnienie popytu od zaspokajania zróżnicowanych oczekiwań czytelników powodowały, że większość tekstów w prasie humorystycznej miała krótkie rozmiary. Formy dłuższe, w tym poematy satyryczne, gawędy humorystyczne oraz poematy heroikomiczne, starano się wydawać jako osobne druki zwarte bądź zamieszczano je w autorskich tomikach satyr i bajek.

Wyrok zapomnienia, który dotknął większość tych satyryków czy humorystów, jest nieodwracalny, choć ostatnio podjęto próby ich częściowej rehabilitacji. Bo to właśnie ówcześni poeci przedstawili „wszystkie udręki cywilizacji, jakich i my dzisiaj doświadczamy. Ukazali pogoń za pieniądzem, mieszczanienie narodu, korupcję instytucji państwowych i społecznych, manipulację opinią publiczną"8. Wierszowana humorystyka pozytywizmu nie stworzyła żadnego dzieła wybitnego, ponadczasowego, choć niektóre utwory Zagórskiego weszły do anonimowego obiegu literatury, dając wzór erudycyjnego komizmu nonsensu — „bigosu historycznego” (Kiedy Kara Mustafa...) lub stając się pieśnią biesiadną (Historia patriarchy Noego). Mimo to jest pouczającym zapisem tamtejszej codzienności - typów, postaw, lęków, nadziei, irytacji, gniewu.

${ }^{8}$ J. Tomkowski, Samobójcy i marzyciele. O zabijanitu poetów, Kielce 2002, s. 28. 
Wszyscy ci satyrycy-artyści lub z pretensjami do artyzmu, wraz z wspaniałymi satyrykami felietonistycznymi; Świętochowskim i Prusem, to mają z sobą wspólnego, że nie stoją ponad swoim czasem. Każdy, jak może, służy mu, nikt go nie wyprzedza; każdy tkwi w jego pojęciach i dążeniach, pragnie tylko usunąć drobne jego cienie, wlaściwe w ogólności naturze ludzkiej lub rzucane przez wlokących się opieszale maruderów — nikt, prócz zakamieniałych konserwatystów, nie kwestionował ducha jego... 9

Stąd formula Wilhelma Feldmana o satyrze jako „negatywnej fotografii czasu, która odwrócona daje portret realny i wierny"10.

Pozytywistyczna refleksja nad humorem ograniczała się do powtarzania zaleceń normatywnej poetyki o unikaniu szydzenia z konkretnych osób, nieprzekraczaniu granicy między satyrą a paszkwilem ${ }^{11}$ i wykazywaniu, iż humor dotyczy uczuć, a opiera się na komicznej sprzeczności. Powtarzano więc i cytowano ${ }^{12}$ popularną Estetykę Karola Lemcke ${ }^{13}$. Z niej wyczytywano naukę o psychospołecznym znaczeniu humoru jako warunku biologicznego zdrowia jednostki, o jego walorach terapeutycznych i relaksacyjnych oraz o związku humoru, jako manifestacji wolności, z sytuacją społeczeństw.

Litości godnym - pisał Lemcke - bywa tam życie ludu, gdzie pospolitą komiczność wykluczono z obyczajów; jest to stan wyśrubowany, szkodliwy dla całości $i^{14}$.

Krakowski inicjator „Biblioteczki Humorystycznej dla Porządnych Ludzi” wykładał, iż „humor nas ze wszystkich stron otacza”, nie powinien więc być jednostronny, ,jeżeli wszechstronne pragnie sobie zjednać upodobanie”. Humorysta pisal, że

stara się o to, żeby się śmiano $\mathrm{z}$ jego pomysłów, a nie $\mathrm{z}$ niego samego - ofiaruje swój dowcip społeczeństwu, a nie społeczeństwo swojemu dowcipowi. [...] Nie masz żadnej rzeczy na świecie, której by się nie dało śmiesznej strony upatrzyć - ja jestem nawet tego zdania, że Stwórca w chwili humorystycznego nastroju świat stworzył, w któ-

\footnotetext{
${ }^{9}$ W. Feldman, Piśmiennictuo polskie ostatnich lat duıdziestu, t. 1, Lwów 1902, s. 42.

${ }^{10}$ Ibidem, s. 37.

${ }^{11}$ Por. T. Ziemba, Estetyka poezji, Kraków 1882, s. 97; B. Grabowski, Teoria literatury (stylu, prozy i poezji) do użytku szkolnego i nauki domowej, Warszawa 1901, s. 81; H. Galle, Teoria prozy i poezji w zarysie, Warszawa 1904, s. 84-85; P. Chmielowski, Wspótcześni poeci polscy..., op. cit., s. 283-284.

${ }_{12}$ Por. P. Chmielowski, Stylistyka polska wraz z nauka kompozycji pisarskiej, Warszawa 1903, s. 105.

${ }^{13}$ K. Lemcke, Estetyka, tł. B. Zawadzki, Lwów 1901.

${ }^{14}$ Ibidem, s. 121.
} 
rym On w chwilach wolnych jakby z książki czyta i z naszych głupstw się naśmiewa ${ }^{15}$.

Wpływ Lemckego widać też w następującym wywodzie:

Najlepszą oznaką zdrowia jest humor wesoły - to powszechnie znana prawda, którą uzasadnia higiena, a potwierdza historia narodów. Ludy szczęśliwe, fizycznie zdrowe a politycznie potężne odznaczały się zawsze w okresach największego swego rozkwitu tryskającym humorem i dowcipem, przeciwnie narody upadłe, fizycznie zmarniałe i skarłowaciałe lubują się w nędznych żartach i płaskich dowcipach. [...] Dziś czasy się zmienily. Śmiać się trudno, bardzo trudno. A jednak zabawa i rozrywka dla ducha znękanego mozolną pracą jest konieczną. Wpływa ona zbawiennie na organizm, odświeża go, uspokaja i wzmacnia. Lecz w takim razie zamiast powtarzać odgrzewane często, wręcz niezdrowe i niemoralne dowcipy naszych pseudo-humorystów, raczej z krynicy ducha narodowego zaczerpnąć nowe zdroje wesołej myśli $[\ldots]^{16}$.

Drugą cechą myśli pozytywistycznej o humorze jest zaskakująca zgodność reprezentantów różnych opcji ideowych w sprawie narodowych elementów humoru. I liberał Chmielowski, i krytycy konserwatywni - Lucjan Siemieński, Stanisław Tarnowski, a głównie Stanisław Koźmian, i na koniec bliski socjalizmowi Wilhelm Feldman — zgodnie domagali się humoru „szczeropolskiego”, odrzucenia wzorów kosmopolitycznych. Chmielowski wytykał Rodociowi naśladowanie Bérangera, Stebelskiemu - Musseta ${ }^{17}$, a o Zagórskim wyrzekł, iż: „Heine i Scheffel byli dla niego wzorami i przewodnikami i to tak dalece, że niekiedy ich pomysły za swoje podawał” ${ }^{18}$. Feldman o lwowskim kole „Szczutka” orzekł: „Satyra ich jest pozbawiona wielkości, humor ich obcy, nic nie mający wspólnego z szczeropolskim, sentyment ich Heine'owski”" ${ }^{19}$. Łagodniejszy dla "Szczutka” był Stanisław Koźmian, bo widział tu „mniej wpływu obczyzny i wiedeńskiej humorystyki”. Generalnie jednak zarzucał humorystyce galicyjskiej, że nie ma podstawy w wesołości Mikołaja Reja, Ignacego Krasickiego, Henryka Rzewuskiego, Aleksandra Fredry czy Radziwiłła Panie Kochanku, ale w wiedeńskich kawiarniach i pisemkach naddu-

\footnotetext{
${ }^{15}$ Szymko [pseud. niezidentyfikowany], O humorze, w: idem, Bomba, „Biblioteczka Humorystyczna dla Porządnych Ludzi”, ser. 1, Kraków 1885, s. 8-9.

${ }^{16}$ Humorystyka. Anegdoty i zdrowe mysti, w: Leopolda Lityńskiego Kalendarz Zdrowia Higieniczny, Informacyjny, Lekarski i Ilustrowany na rok pański 1892, Lwów [1892], s. 42.

17 Zob. P. Chmielowski, Zarys najnouszej literatury polskiej (1864-1897), op. cit., s. 356-357.

${ }^{18}$ Idem, Wspótcześni poeci polscy..., op. cit., s. 265.

${ }^{19}$ W. Feldman, op. cit., s. 38.
} 
najskich $^{20}$. Do Koźmiana zbliżał się Chmielowski, definiując polski dowcip jako: „dobroduszny, żartobliwy i rubaszny, chętnie osobę samą dowcipkującego wciągający w dziedzinę wyśmiewanych, ażeby zmniejszyć ostrość wyśmiania; zowiemy go zazwyczaj jowialnością"21. Autor Wspótczesnych poetów polskich na przykładzie satyr Rodocia sformulował teorię satyry, która jest wyrazem milości, a nie nienawiści społecznej, satyry budowanej na obrazach ogólnych, a nie „inkryminacjach osobistych”. Uśmiech — tłumaczył —

dowodzi pobłażliwości, a raczej wyrozumiałości koniecznej w życiu zarówno towarzyskim, jak społecznym, dowodzi zarazem, że Rodoć kocha ludzi pomimo ich wad i słabostek. Stąd i w czytelniku powstaje to błogie uczucie, że pomimo wszystko, co można złego powiedzieć o ludziach, są oni przecież godni kochania, że świat nie jest zbiorem jakichś wyrzutków i śmieci. [...] Kto chce ludzi poprawiać, musi ich przede wszystkim kochać, bo słowa płynące $\mathrm{z}$ nienawistnego usposobienia mogą wprost przeciwny wywrzeć skutek; przejmując oburzeniem, rodzą nienawiść i zamiast doprowadzić do porozumienia i harmonii, a choćby tylko do rozumnej walki, czynią ją coraz zawziętszą i coraz bardziej zaślepioną²2.

Humor w takich koncepcjach był gwarantem i kontrolerem ładu społecznego, ujawniał dobre i zabawne strony rzeczywistości, stanowił też element kultury i charakterologii narodowej. Niewątpliwie obawa przed radykalną dezorganizacją życia społecznego, którą zapowiadały idee socjalistyczne, zbliżała warszawskich liberałów i galicyjskich konserwatystów oraz demokratów. Nieprzejednany przez całe lata wróg stańczyków i "Czasu” - Włodzimierz Zagórski w końcu stał się jego pracownikiem... Łatwo też dostrzec w jego twórczości inspirowanie się narodową tradycją, zalecaną przez konserwatystów, jak widać z Peregrynacji J. O. X. Wojewody Wileńskiego do księżyca (trawestacja utworu Juliusza Słowackiego Święcone u J. O. Ks. Radziwitta Sierotki). Daleki od paszkwilu humor, który wprowadza dysonanse społeczne, humor korygujący

20 Zob. S. Koźmian, Listy o Galicji do „Gazety Polskiej” 1875-1876, Kraków 1877, s. 128. Polemiki o pojmowanie polskiego humoru (szlachecki czy mieszczański?) między stańczykami a lwowskimi satyrykami omawia Stanisław Frybes (op. cit., s. 15-26).

${ }_{21}$ P. Chmielowski, Stylistyka polska..., op. cit., s. 103. Rodzime źródła satyry Antoni Bądzkiewicz widział w klechdach, zwłaszcza z diabłem w roli bohatera. „Szydzili Polacy ze świata, ale bez drażliwości, nie lżąc, ale dowcipkując i śmiejąc się z politycznego i domowego życia oraz z charakteru swojego. Rodzaj ten humorystyki znany pod imieniem «bajów», «żartów», «śmieszków» niewątpliwie był rodzimym źródłem satyry aż do tego czasu, w którym na literaturę naszą wpływ satyry rzymskiej objawiać się zaczął. Wpływ ten nie zmienił ducha twórczości rodzimej, i satyra nasza pod piórem najznakomitszych jej uprawiaczy nigdy nie była podobną do Juwenalisowej i Persjuszowej"(A. Bądzkiewicz, Teoria poezji $w$ zwiqzku z jej historiq opowiedziana, Warszawa 1875, s. 239).

22 P. Chmielowski, Wspótczéśni poeci polscy..., op. cit., s. 284-285. 
wady ludzkie i utrzymujący społeczeństwo w stanie zdrowia, humor stojący na straży narodowej charakterologii i podtrzymujący cechy narodowe, słowem - humor solidarystyczny i rodzimy najlepiej ucieleśniały różne satyryczne „piosnki” w typie Artura Bartelsa oraz dłuższe poematy humorystyczne. Teoretycy ówcześni zwykle wyróżniali "poezję dydaktyczną" jako osobny rodzaj literacki (zdecydowanie protestował przeciw temu Antoni Bądzkiewicz, uznający dydaktyzm za „przeciwny celowi poezji”, tj. tworzeniu ideałów $w^{23}$ ). Omawiano więc taki poemat jako model bliski satyrze i listowi poetyckiemu ${ }^{24}$, „epos satyryczno-humorystyczny”25, „poemat satyryczno-humorystyczny”, będący bajką lub satyrą „rozszerzoną tak bardzo, że tworzy cały poemat”" Dla Henryka Gallego poemat to „nowela lub niewielka powieść, pisana mową wiązaną” o zróżnicowanej treści i formie („może więc być poemat dramatyczny, liryczny, religijny, sielankowy itd." ${ }^{27}$ ). W praktyce krytycznoliterackiej repertuar takich pojęć był poszerzany: „Fraszka ta, jak ją nazywa autor, jest rodzajem komicznego i satyrycznego eposu z dziejów wiejskiej szlachty"28. Model czy prototyp gatunkowy ${ }^{29}$ i uznawany w semantyce prototypu tzw. poziom podstawowy mieszczą się w klasie pojęć: epos, poemat, wiersz, humor, satyra. Mentalną reprezentacją jest tu poemat heroikomiczny.

Poemat humorystyczny w epoce pozytywizmu wykształcil kilka wyraźnych form gatunkowych: poemat heroikomiczny, opisujący świat w kategoriach ostrego przeciwstawienia wartości, konfliktu przedstawianego jako zbrojne starcie; poemat panoramiczny czy opisowo-panoramiczny, stanowiący cykl obrazków („fotografii”) z określonych miejsc, karykaturalnie wyjaskrawionych lub satyrycznie ocenianych - jednym z wariantów jest trawestacja Pieśni o ziemi naszej Wincentego Pola ${ }^{30}$; afabularny bądź o zredukowanej fabularności żartobliwy „poradnik” (dla „noworodków”, „nowożeńców”,

${ }^{23}$ A. Bądzkiewicz, op. cit., s. 98.

${ }^{24}$ Zob. T. Ziemba, op. cit., s. 98.

${ }_{25}$ A. G. Bem, Teoria poezji polskiej z przyktadami w zarysie popularnym analityczno-dziejourym, Petersburg 1899, s. 170-174 (Bem używa też nazw „poemat” i „poemacik”).

26 Wl. Weychertówna, Stylistyka. Teoria prozy i poezji, Warszawa 1901, s. 168.

${ }_{27}$ H. Galle, op. cit., s. 92-95. Autor mocno podkreślał, iż poemat „formą tylko różni się od noweli”, gdyż przedstawia niewielki wycinek życia. Traktował go jako gatunek epicki, nie wyróżniał rodzaju dydaktycznego.

${ }^{28}$ Eada [J. Gnatowski], Przegląd artystyczny i literacki, „Niwa” 1882, z. 183, s. 192. Rzecz dotyczy utworu Włodzimierza Wysockiego Wszyscy za jednego. Fraszka (Kijów 1882). Piotr Chmielowski w Zarysie najnowszej literatury polskiej... (op. cit., s. 344) nazywa utwory Aleksandra Morgenbessera „poemacikami żartobliwo-satyrycznymi”, dystansując się od autorskiego określenia „humorystyczne”, Ogniem i mieczem Kazimierza Bartoszewicza uznaje za „satyrę”, a Klemensa Bąkowskiego obszerny poemat heroikomiczny Pan Mateusz czyli ostatni zajazd na Kleparzu. Historia akademicka w 6 pieśniach (Kraków 1885) nazywa „wierszowaną fraszką". Już rozmiary tych utworów przeczą takim klasyfikacjom.

29 Teorię prototypów zastosowaną do genologii omawia Bożena Witosz (Genologia lingwistyczna. Zarys problematyki, Katowice 2005).

${ }^{30}$ Por. W. Zagórski, Pieśń o izbie naszej, w: idem, Z teki Chochlika. O zmierzchu i śnicie (1865-1881), Lwów [1881], s. 21-30: 
„konkurentów”, „żonatych””11); poemat dygresyjny (Imagina Konopnickiej, twórczość Stebelskiego); humorystyczny obrazek historyczny (częsty u Or-ota, np. Imć pan Duda $w$ amorach, Gwiazdka panny Basi); gawęda (Ludwik Niemojewski, Włodzimierz Wysocki); list (Henryk Merzbach i Włodzimierz Wolski, Listy z Belgii, Rodoć, Pogadanki lwowskie Roku Pańskiego Wystawy Krajowej pisane); formy balladowo-legendowe (wyjątkowa popularność diabła Boruty jako typu rodzimego humoru ${ }^{32}$ ). W tym repertuarze narracyjnych form humorystyczno-satyrycznych poemat heroikomiczny miał wiele zalet i jedną poważną wadę. Zaletą była struktura, która już w Oświeceniu uległa rozluźnieniu, dopuszczając słabo związane $\mathrm{z}$ akcją dygresje, poprzez które wprowadzano różne aspekty wypowiedzi podmiotowej ${ }^{33}$, a także wyrazista relacja nadawca-odbiorca, umożliwiająca bezpośrednią perswazję i ariostyczne rozsnuwanie tematu na oczach czytelnika. Dzięki tym cechom strukturalnym poemat heroikomiczny mógł łatwo inkorporować wstawki gatunków lirycznych, jak pieśni, latwo też mógł wiązać się z gawędą

\footnotetext{
A czy znasz ty, bracie młody,

Twoich posłów chorowody;

Twoich „Dzikich”, twych „Stańczyków”,

„Mameluków” i „Jurczyków”?

A czy znasz ty, bracie młody,

Twojej Izby bujne płody:

Wnioski, wneski i wnesenia

Czekające odroczenia? [s. 21].
}

Inny przykład zaczerpnięty z utworu pt. $Z$ dzisiejszych legend, „Diabeł” R. 21: 1889, nr 1, s. 6 :

$$
\begin{aligned}
& \text { Znasz ty, bracie, znasz ty, kandy } \\
& \text { Starożytny kopiec Wandy? } \\
& \text { Znasz ty, bracie, gdzie Mogiła, } \\
& \text { Wioska piękna, wioska miła, } \\
& \text { Której środkiem do Wisełki } \\
& \text { Niesie Dłubnia wód perełki? }
\end{aligned}
$$

(Poemat opowiada o wylewie rzeki, który sparaliżował pracę licznych tu młynów, bowiem zniszczył „Jaz, który budował pono / Dla Mogilan Krakus z żoną").

${ }^{31} \mathrm{Za}$ „dłuższe poemaciki satyryczne” uznają je Piotr Chmielowski (Wspótcześni poeci polscy..., op. cit., s. 266) oraz Jerzy Korfel (op. cit., s. 133). Pisali je Włodzimierz Zagórski i Emanuel Goździewicz (Poradnik dla żonatych, Kraków 1886). Zob. też: L. G. Kajtuś, Poradnik dla panien chcacych wyjść za mąż. Studium etyczno-psychologiczno-społeczne dla użytku ptci nadobnej, „Diabeł” R. 12: 1885, nr 4-7.

${ }^{32}$ Zob. B. Czerwieński, Boruta diabeł tęczycki, w: idem, Poezje, Lwów 1881; F. Świderski, Diabeł Boruta w Potoku Ztotym. Ramota humorystyczna, w: idem, Pisma humorystyczne, z. 1, Częstochowa 1883; W. Wysocki, Gawęda wesoła $w$ dni słotne do czytania nader pożyteczna, w: idem, Satyry i fraszki, Kijów-Odessa 1894, s. 5-43 (bohaterem poematu jest Bieś - Bismarck).

${ }_{33}$ Zob. G. Bystydzieńska, hasło Poemat heroikomiczny, w: Słownik rodzajów i gatunków literackich, red. G. Gazda, S. Tynecka-Makowska, Kraków 2006, s. 545-547; W. Pusz, Tok narracyjny oświeceniowego heroicomicum, „Zeszyty Naukowe Uniwersytetu Eódzkiego” seria 1, 1974, z. 104; idem, Poemat heroikomiczny, w: Stownik literatury polskiego ośniecenia, red. T. Kostkiewiczowa, Wrocław 1977, s. 482-488. 
oraz poematem dygresyjnym. Spelniał zatem warunki rodzimości (gawęda, ramota) oraz nawiązywania do tradycji literackiej. Przez samo przywoływanie wzoru eposu i wartości z eposowego świata, uwznioślanie cnót i prezentowanie ideałów, kontrastująca z nimi rzeczywistość, będąca treścią poematu, wydawała się wystarczająco banalna, płaska, licha i marna, dlatego przesada, karykatura i gwałtowność satyrycznej napaści mogły być stonowane. Postulat umiaru też więc był spełniony. Rekwizytornia antycznej kultury i siła umownych konwencji literackich stanowily element zabawy formą, zatem dodatkowo rozbrajały i lagodziły negatywne emocje. Konwencje pozwalały napiętnować dostrzeżone wady, ale w sposób na tyle ogólny i bezosobowy, że intencje satyryczne nie jątrzyły społeczeństwa, lecz raczej zawstydzały. Wadą byl konwencjonalny i erudycyjny rodowód. Cytaty i aluzje, w tym z Monachomachii oraz Myszeidy Krasickiego, a także z Pana Tadeusza Mickiewicza, tworzyły wysoką barierę erudycyjno-kulturową. Zawężały krąg odbiorców, przemawiały tylko do tych, którzy byli w stanie deszyfrować ten kod, zwracały się do własnego kręgu ideowego, przekonywały tych, którzy i bez tego wyznawali wartości autora. Ich główną wadą była więc hermetyczność przekazu, wskutek czego oddziaływanie społeczne poematu humorystycznego nie mogło być duże.

Miał on bardzo różne rozmiary. Napoleon XIII. Poemat heroikomiczny $w$ dwudziestu pieśniach Krystyna Ostrowskiego ${ }^{34}$ liczy stron 297. Obrona Sokotowa. Śpiew bohaterski w IX pieśniach Aleksandra Morgenbessera ${ }^{35}$ już tylko 153. Niewiele ustępuje mu rozmiarami Klemensa Bąkowskiego Pan Mateusz czpli ostatni zajazd na Kleparzu13. Inne mają od kilku do kilkudziesięciu stron. Krótsze formy pojawiały się jako wierszowane wstawki w prozatorskich felietonach („kronikach”" $\left.{ }^{\prime 3}\right)$. W prasie humorystycznej dość często spotykamy wyraźne stylizacje heroikomiczne opisujące pojedyncze zdarzenie; są raczej niedługie, dwuszpaltowe. Konwencje gatunkowe, projektujące zarazem styl lektury, były — najwidoczniej — szczególnie ważne, skoro autorzy bardzo zdecydowanie powiadamiali o nich czytelników. Czynili to na dwa sposoby:

1. Poprzez zabiegi słowotwórcze w tytułach, aluzyjnie wskazujące na znane eposy antyczne jako wzory genologiczne: Władysława L. Anczyca Döllingeriada to kontaminacja słów Döllinger i Iliada, utwór opowiada o krakowskich perypetiach doktryny zaprzeczającej nieomylności papieża; Lippertiada ${ }^{38}$ - komiczna opowieść o pewnym niemieckim litografie nazwiskiem Lippert, którego rajcy krakowscy nie chcieli przyjąć do gminy Kraków w ramach retorsji za „rugi pruskie”; Galilejada ${ }^{39}$ — wywodzi się

${ }^{34}$ Zob. H. Ś. [K. Ostrowski], Napoleon XIII. Poemat heroikomiczny w duvidziestu pieśniach, Paryż 1871.

${ }^{35}$ Zob. A. Morgenbesser, Obrona Sokołowa. Śpiew bohaterski w IX pieśniach, Wiedeń 1862.

${ }^{36}$ Zob. K. Bąkowski, Pan Mateusz czyli ostatni zajazd na Kleparzu. Historia akademicka w' 6 pieśniach, Kraków 1885.

37 Por. K. Bartoszewicz, 40 kronik Kazimierza Bartoszewicza, Kraków 1884, s. 17-19 (w formie poematu heroikomicznego omówiono konkurs na pomnik Mickiewicza).

${ }^{38}$ Druk: „Diabel” R. 17: 1885, nr 22, s. 6.

${ }^{39}$ Druk: ibidem, R. 16: 1884, nr 4-5. 
od słów: Galicja plus Iliada, zawiera opowieści drukowane w „Diable” o zabawnych perypetiach życia społeczno-kulturalnego prowincji; Muzyko-machia ${ }^{40}$ - aluzja słowotwórcza do poematu Krasickiego.

2. Poprzez nazwy genologiczne w tytułach lub podtytułach, rzadziej w samym utworze, choć i tak się zdarzało ${ }^{41}$. Mamy tu n przykład tytuły: E po peja [to i nast. wyróżn.- T. B.] o bohaterze dni, $w$ których na plantacjach salinarnych $w$ Bochni przygrywa muzyka górnicza ${ }^{42}$; Przed wyborami. Tragikomiczna e po peja napisana przez Chtopa43; Whadysław Anczyc, Döllingeriada. Po e mat bo hatersk $i^{44}$; Krystyn Ostrowski, Napoleon XIII. Poemat heroikomiczny...; Aleksander Morgenbesser Palestra czyli wojna prawników. W siedmiu pieśniach ${ }^{45}$ oraz Obrona Sokotowa. Ś piew boh ater ski, a także: Myslacy burmistrz. Poe mat hu morystyczny w siedmiu piésniach ${ }^{46}$. Niektóre nazwy genologiczne aluzyjnie wskazywaly Pana Tadeusza, który w sporym stopniu odzwierciedlał cechy heroicomicum, jest to więc pośrednie sygnalizowanie wzoru eposu. Tu warto wymienić poemat, którego autorstwo budzi wạtpliwości: Powstanie $w$ Czernichowie w roku 1888. Historia szlacheck a w siedmiu pieśniach (Kraków $1895^{47}$ ). Wyróżnia się sporymi walorami ideowo-artystycznymi utwór Klemensa Bąkowskiego Pan Mateusz czyli ostatni zajazd na Kleparzu. Historia a kademick a $w 6$ pieśniach. Wbrew podtytułowi utwór Kazimierza Bartoszewicza Ogniem i mieczem. Powieść z ostatnich dni czerwca ${ }^{48}$ jest po-

${ }^{40}$ Druk: ibidem, „Diabel” R. 16: 1884, nr 3.

${ }^{41}$ Por. Borba, „Diabel” R. 16: 1884, nr 5, s. 7. Jest to wierszowany konspekt planowanego „eposu wierszem" o zamieszkach, które miały miejsce w krakowskiej Radzie Miejskiej za prezydentury Ferdynanda Weigla. W istocie utwór jest mikropoematem heroikomicznym z podziałem na pieśni; o stanie niegotowości struktury świadczy gramatyczny tryb przypuszczający:

W trzeciej pieśni byłaby borba opisana

Napad wodza Faustyna i wodza Jordana.

Co taki tam odnieśli triumf językami,

Że się mogą o lepsze mierzyć z przekupkami.

42 Druk: „Diabel” R. 20: 1888, nr 13, Dodatek, s. 2.

${ }^{43}$ Druk: ibidem, R. 21: 1889, nr 12, Dodatek, s. 1 (autor użył pseudonimu „Włościanin z brzeskiego powiatu”).

44 Zob. W. Anczyc, Döllingeriada (1871), w: idem, Wiersze i poematy, opr. M. Szyjkowski, t. 2, Kraków 1908.

${ }^{45}$ Druk: Lwów 1880.

${ }^{46}$ Druk: Lwów 1881.

${ }^{47} \mathrm{Na}$ karcie tytułowej podpisany jest Z. Z. Miłkowski, co dla piszących o Teodorze Tomaszu Jeżu było wskazówką, iz pisarz użył wyjątkowo własnego nazwiska. Jego bibliografie przypisują mu autorstwo poematu. Jednak nie uwzględniają innego dziełka Przygody kapelana przez autora Poustania $w$ Czernichowie w sześciu pieśniach (Kraków 1895), również podpisanego Z. Z. Miłkowski. Są mocne przesłanki, aby autorstwo przypisać księdzu Mateuszowi Jeżowi, znanemu później literatowi, gdyż wówczas kapelanem czernichowskim był właśnie ks. Jeż. Na ten temat zob. D. Świerczyńska, Kłopoty z atrybucja, czyli uwagi o ustalaniu autorstwa, w: Pogranicza literatury. Ksiega ofiarowana Profesorowi Januszowi Maciejeuskiemu na Jego siedemdziesięciolecie, red. G. Borkowska, J. Wójcicki, Warszawa 2001, s. 359.

${ }^{48}$ Druk: Kraków 1884 (autor użył pseudonimu: „C. K. uprzyw. kronikarz głów. M. Krakowa”). 
ematem humorystycznym. Studiując zawarte w tytułach nazwy genologiczne, dostrzegamy, że tradycje humorystyki oświeceniowej dopełniano tradycjami romantycznymi (ilość trawestacji bajek Krasickiego, utworów Mickiewicza, zwłaszcza ballad, a także psalmów Zygmunta Krasińskiego i Kornela Ujejskiego jest naprawdę duża zarówno w osobnych tomikach bajek i satyr, jak i w prasie humorystycznej). Nadto, że sfera heroicomicum jako umowna przestrzeń pewnej egzotyki kulturowej (grecka i rzymska onomastyka) wchodzi w symbiozę z rodzimymi gatunkami wypowiedzi: gawędą, facecją, anegdotą myśliwską, ramotą, toastem, pochwałą. Literaci starszego pokolenia, a w każdym razie debiutujący przed rokiem 1863, jak Artur Bartels, Aleksander Morgenbesser, Ludwik Niemojewski czy Faustyn Świderski, wprowadzali do takich poematów narrację gawędową, zachowując rodzimy humor szlachecki. Świderski na przykład opowiada w kolejnych pieśniach poematu o Muzach, o wdrapaniu się na Parnas („Dostawszy ostrą od Charona burę, / Żem Styks przejechal, nie mając paszportu"49) i o piorunach w ręku Jowisza po to, aby zwyczajnie zadziwić konceptem i pokryć żartem wzruszenie przy składaniu hołdu Kraszewskiemu na jego jubileusz pięćdziesięciolecia pracy. Komplet rekwizytów heroikomicznych widzimy w innym jego poemacie, którego podtytuł sygnalizuje stan genologicznej niepewności: Wojna owadów przeciwko profesorowi Wadze. Coś na ksztatt epopei ${ }^{50}$. Wyraźne cechy gawędy zdradza Pospolite ruszenie wszelkiego rodzaju stworzeń $i$ elementów przeciwko szlachcicowi wiejskiemu. Po emat hu morystyczn $y^{51}$, a także Napad Tatarów. Opowiadanie humorystyczne z prawdziwego $z$ darzenia ${ }^{52}$. Elementy struktury facecji i anegdoty myśliwskiej widać w utworach Wielka defilada żab. Ode zwa hu moryst yczna ${ }^{53}$ czy Wielki koncert i dzien radosny wszelkiego rodzaju zwierzyny w pewnej parafii zamieszkatej, ex re odjazdu znakomitego mystiwego. Ra mo o a humorystyczna ${ }^{54}$. Na pograniczu gawędy i legendy (konwencja snu po nadmiarze alkoholu...) sytuuje się Diabet Boruta $w$ Potoku Ztotym. Ra mota humorystyczna.

Do postulatu humoru, który jest wyrazem społecznego zdrowia i pogody ducha, który widzi świat z dobrej i złej strony, który ludzi zbliża, a nie dzieli, uczy i daje dobre rady zamiast gromić i szydzić; humoru rodzimego, który obce wzory „przepolszcza” i unarodawia (częsty motyw vitrum gloriosum wzięty z Monachomachii), najbardziej zbliżyli się Faustyn Świderski i Aleksander Morgenbesser. Poematy Świderskiego, podobnie jak powiastki dla ludu i literatura dla dzieci ${ }^{55}$, stanowią dowód na nieostre granice

${ }^{49}$ F. Świderski (Ex-Bocian), Jubileusz. Ramota heroi-komiczna, w: idem, Pisma lumorystyczne, z. 1, Częstochowa 1883 , s. 9.

${ }^{50}$ Zob. ibidem, s. 13.

${ }^{51}$ Zob. ibidem, s. 42-57.

52 Zob. ibidem, s. 38-41.

${ }^{53}$ Zob. ibidem, s. 23-26.

${ }^{54}$ Zob. ibidem, s. 26-29.

${ }_{55}$ „Dzieje ojczyste dla ludu”, wielokrotnie wznawiane, jak w przypadku Lucjana Siemieńskiego, połączone z gatunkiem ,śpiewów historycznych”, dały w efekcie sporo wierszowanych wykładów oj- 
między romantyzmem a pozytywizmem. Niektóre teksty, powstałe w latach pięćdziesiątych wieku XIX, a przedrukowane w latach osiemdziesiątych, nie traciły aktualności. Ideały pracy i gospodarności jako warunki utrzymania bytu swego i rodziny oraz jako czyn patriotyczny (postęp materialny broni rodzinnej ziemi przed ekspansją niemiecką) są niezmienne. Nie zmienia się solidaryzm sąsiedzki, gromadzki oraz kult wiedzy i nauki, których wartość widzi się w zastosowaniach praktycznych. Dyskretnie wplecione motywy dawanych woźnym w rublach łapówek oraz wyraźna niechęć do rozwiązań rewolucyjnych to satyryczne aktualizacje w Wojnie owadów... i zarys stanowiska ideowego bliskiego kręgom Towarzystwa Rolniczego. Jako żart i zabawa poematy humorystyczne Ex-Bociana odpowiadają postulatom i Stanisława Koźmiana, i Piotra Chmielowskiego. W inwokacji do Wojny owadów przeciwko profesorowi Wadze można się dopatrzeć kontaminacji stylu heroicomicum oraz gawędy (zapowiedź tematu śpiewu bohaterskiego z jednoczesnymi zwrotami do adresata, które pełnią funkcje fatyczne, wyznaczają pole poufnej i bezpośredniej interakcji nadawczo-odbiorczej j6).

Wojnę opiewam - słuchajcie, panowie!
Wojnę krzyżową zwaną kiedyś świętą,
Włosy wam pewno powstaną na głowie,
Tak była straszną, tak była zaciętą -
Słuchajcie przeto - panowie, uwaga!
Najprzód wam powiem, kto to jest pan Waga ${ }^{57}$.

Przedstawiwszy uczonego biologa, który złowione owady „męczy i srodze zabija”, choć go usprawiedliwia to, iż „rozum ludzki, naukę rozwija”, narrator przedstawia kontrakcję owadów. Talentem oratorskim wyróżnia się chrabąszcz, który wzywa owady:

Zemsty, panowie! Zemsty nam potrzeba -

Quousque tandem abutere Vaga

Patientia nostra! — to straszna zniewaga! ${ }^{58}$

Armia owadów, uszykowanych do boju według systematyki Linneusza, gotowa była ruszyć na Wagę. Wezwani przed oblicze Jowisza do trybunału wywodzą swoje racje, zarzucając biologowi lekceważenie teorii metempsychozy:

czystej historii przeznaczonych dla ludu i dla młodzieży. Były to abecadlniki, śpiewy uzupełniane wykładem oraz rymowane syntezy dziejów. Pisali je epigoni romantyczni oraz twórcy pozytywistyczni: Władysław Ludwik Anczyc, Władysław Bełza, Józef Chociszewski, Maurycy Dzieduszycki, Seweryna Duchińska, Maria Ilnicka, Maria Konopnicka, Teofil Nowosielski.

${ }^{56} \mathrm{O}$ roli inwokacji w gawędzie wierszowanej, szczególnie w ,apologizującej przeszłość gawędzie historycznej", pisze Krzysztof Stępnik (idem, Poetyka gawędy wierszowanej, Wrocław 1983, s. 68-71).

${ }^{57}$ F. Świderski, Wojna owadów przeciwko profesorowi Wadze. Coś na kształt epopei, op. cit., s. 13.

${ }^{58}$ Ibidem, s. 14. 
Być może w raku dusza Hannibala,

A przeleciawszy Karpaty i Tatry,

W skoczku uszatym dusza Kleopatry ${ }^{59}$.

Część sił owadzich, zarzucając innym oportunizm i zdradę, wywołuje rewolucję i rusza do natarcia:

Ten wchodzi w rękaw — ów ciśnie się w oczy,

Każdy, jak może, profesora goni ${ }^{60}$.

Jowisz zirytowany owadzią samowolą sięga po pioruny, a burza i ulewa rozpędzają waleczną armię.

Autor nawiązuje do wspomnianego wyżej dzieła w inwokacji do Pospolitego ruszenia wszelkiego rodzaju stworzeń i elementów przeciwko szlachcicowi wiejskiemu:

Panowie! Kiedy straszną opiewalem wojnę,

Którą wiodły owady pod Potocką górą,

Daliście mi oklaski i pochwały hojne $[\ldots]^{61}$

Treścią poematu jest żywot szlachcica, który na nieurodzajnym gruncie, na posiadłości obciążonej powinnościami i zapisami familijnymi, co uniemożliwia jakiekolwiek reformy agrotechniczne, boryka się z nieszczęściami spadającymi nań w stopniu trudnym do wyobrażenia. Autor przyrównuje je do „napadu Hunów, Allanów, Gotów, Wizygotów i Ostrogotów". Bohaterowi nie darzy się w pracy na roli, co wywołuje gniewy żony. Zlożony chorobą nie dopilnowal robót, wpadł przeto w długi i omal mu nie zasekwestrowano majątku. Następuje dalej komiczny w przesadzie opis wszystkich możliwych plag i szkód, które dotykają pechowego ziemianina:

Wszystko - w ogóle wszystko — dzikie czy domowe,

O tym tylko rozmyśla, nad tym suszy głowę,

Ptaki, gady, robaki, owady, zwierzęta,

Których tam biedny rolnik nigdy nie spamięta,

Gotowi wciąż do walki przeciw rolnikowi,

Medytują i myślą, jak kraść zysk Pawłowi ${ }^{62}$.

Już więc pod koniec nierównego boju, gdy na scenie pojawia się zwiastun ostatecznego nieszczęścia:

\footnotetext{
${ }^{59}$ Ibidem, s. 21.

${ }^{60}$ Ibidem, s. 21.

${ }^{61}$ Idem, Pospolite ruszenie wszelkiego rodzaju stworzeń i elementów..., op. cit., s. 42.

${ }^{62}$ Ibidem, s. 51.
} 
Ej, ty, na lichej szkapie, gdzie tak pędzisz, Żydzie?

Czy ci o jaki handel, czy o szabas idzie? [...]

Nie bój się — będziesz na czas dziś na licytacji63 -

przychodzi pomoc. Sąsiad „poratował” pożyczką, wyjaśniły się sprawy własnościowe, bohaterowi odmienilo się życie, toteż autor w epilogu wygłasza apologię Instytutu w Marymoncie, który uczy nowoczesnego gospodarowania. Tak się poemat humorystyczny przeistoczył w powieść tendencyjną.

Podobne rozwiązanie (odnalezienie satysfakcji w pracy, a nie w służbie Pegazowi) przynosi Młodość poety Kazimierza Bartoszewicza. Autor parodiuje różne style liryki romantycznej, osobistej oraz język poezji pozytywistycznej (podobnie jak Asnyk w Napadzie na Parnas), kończąc poemat apelem:

Bracia poeci! Gdy chwila ponura

Do cnych serc waszych wsączy jad trucizny,

Zerwijcie z chwałą, rzućcie na bok pióra,

Chwyćcie się bydła i nierogacizny!... ${ }^{64}$

Niektóre poematy Morgenbessera ${ }^{6 \overline{5}}$ można uznać za wierszowane wersje powieści Michała Bałuckiego Pan burmistrz z Pipidówki oraz Jana Lama Wielki świat Capowic. Unieśmiertelnił, mówiąc stylem heroikomicznym, galicyjską prowincję, podniósł do znaczenia równego historycznej Troi miasta Pacanów i Jarosław. W Pacanowie, w karczmie Pod Ślimakiem, zaczyna się akcja poematu w siedmiu pieśniach Palestra czyli wojna prawników. Toczy się według schematu bajkowego: chytrus przechytrzony. Świat przedstawiony odwzorowujący realia staroszlacheckie, zwroty do adresata, wyraźna rzewność i ewazyjność zbliżają utwór do gawędy. Bohaterem jest młody dependent, zarazem sprytny w wynajdywaniu kruczków prawnych pozwalających albo wygrać sprawę, albo przynajmniej odwlekać w nieskończoność jej rozstrzygnięcie, jak też skory do pochopnych obietnic dawanych młodym kobietom. Podstępem, podając się za narzeczonego dziewczyny, która spoliczkowała jego adwersarza, doprowadza do ucieczki rywala z miejsca, w którym miano rozstrzygnąć spór o ziemię. Nieobecność adwokata-powoda przynosi wygraną dependentowi. Rywal jednak doprowadza

\footnotetext{
${ }^{63}$ Ibidem, s. 52.

${ }^{6+}$ C. Hr. Ypka [K. Bartoszewicz], Młodośc poety, w: idem, Z wesotych chwil, Kraków 1876, s. 34.

${ }^{65}$ Najlepszy artystycznie heroikomiczny poemat historyczny Obrona Sokołowa traktuje o obronie miasta przed najazdem tatarskim i jest tyleż żartobliwą apologią mieszczańskiego patriotyzmu oraz pomysłowości i męstwa, co satyrycznym przedstawieniem ciasnoty umysłów. Z uwagi na czas powstania (1862) należałoby go rozpatrywać w kontekście ówczesnych planów politycznych co do roli mieszczaństwa w organizacji powstania, a w planie historycznoliterackim - w kontekście epiki historycznej Michała Bałuckiego, Jana Lama i Mieczysława Romanowskiego. Morgenbesser byl, dodajmy, autorem śpiewów historycznych i opracowań historiograficznych.
} 
do porażki bohatera podczas egzaminu adwokackiego, a na domiar złego przed sądem przypomina o skutkach kanonicznych publicznie danej obietnicy małżeństwa... Przegrany porzuca adwokaturę i nadzieje na posiadanie wioski szlacheckiej, żeni się z mieszczanką i znajduje satysfakcję w pracy kowala. Zakończenie jest tak optymistyczne, jak we wczesnych powieściach Bałuckiego O kawat ziemi czy Byle wyżej.

Ciekawszy, bo odważniej wprowadzający elementy satyryczne, jest poemat Morgenbessera Myślacy burmistrz. Tu autor wyraźnie zbliża się do satyrycznego obrazu prowincji z powieści Bałuckiego i Lama. Wskutek osobistego sporu burmistrza z aptekarzem zaktualizowano w mieście starą ustawę zabraniającą dręczenia zwierząt. Dręczyl, naturalnie, aptekarz preparujący marnej jakości trutki na muchy, myszy i szczury, przez co zwierzęta cierpiały, nie mogąc skonać. Aptekarza złapano też na gorącym uczynku, jak znęcal się nad pijawkami używanymi w celach leczniczych. Prawdziwe wzburzenie w mieście zaczęło się jednak, gdy aresztowano kilkoro Żydów, którzy nie chcieli ulżyć lichej szkapie zmuszanej do ciągnięcia wozu ze zbyt dużą liczbą pasażerów. Oburzeni wyznawcy Mojżesza na naradzie wojennej w starej bożnicy postanawiają odbić więźniów. Hetman ich woła:

Dziś nie czas wody wlewać do gorzałki, Ale najtęższej trza pochwycić palki

I bić, i łamać w szalonej wariacji,

Nie czas wam - mówię — dziś do szpekulacji,

Nie czas dziś łokci skróconych dobierać,

Lecz najdluższymi drągami nacierać,

I walić w bramę, w żelazne drzwi godzić,

By $z$ furdygarni braci wyswobodzić.

Nie czas fałszywe kłaść funty do czary,

Lecz co największe dobierać ciężary

I na łby miotać tym przeklętym wrogom,

Tym Filistynom, mniemanym pól-bogom ${ }^{66}$.

I byliby walne odnieśli zwycięstwo pod ratuszem, gdyby nie podstęp sekretarza, któremu burmistrz w zamian za wygraną obiecał rękę córki. Żydowskim zastępom zadawał on pytania, na które odpowiadali wmieszani w tłum szewczykowie. Pytania i odpowiedzi były cytatami z obrzędu katolickiego chrztu (chcę wiary, wyrzekam się szatana, chcę być ochrzczony). Sekretarz był zarazem... naczelnikiem straży ogniowej:

A wtem się bramy rozwarły podwoje,

Z sikawki wody wylały się zdroje

${ }^{66}$ A. Morgenbesser, Mystąc burmistrz, op. cit., s. 47. 
Na lud wybrany, na pejsy, na brody, W ciężkim frasunku dla serca ochłody.

A gdy ten strumień wznosi się rzęsisty, $\mathrm{Z}$ balkonu dźwięczy znów głos uroczysty,

A lud wybrany truchleje, gdy słucha: „Więc was chrzczę w imię Ojca, Syna, Ducha!"67

Fortel uratował dobre imię burmistrza, przywrócił porządek w mieście, pogodził zwaśnionych i połączył zakochanych. Optymistyczny finał nie przesłania jednak przygnębiającego obrazu żałosnych kompetencji zawodowych, miałkości umysłowej, kłótliwości i niskiego poziomu etycznego galicyjskiej administracji prowincjonalnej, jak również obrazu arogancji i pychy bogatych Żydów w stosunku do uboższych współplemieńców, a także dezorganizacji etyczno-obyczajowej tej (tylko pozornej) wspólnoty.

W poematach dotykano też bieżących spraw i konfliktów, które przedstawiano w stylu komicznie zniekształcającym reguły eposu bohaterskiego. Tu już nie szczędzono nazwisk różnych powag życia publicznego, zwłaszcza stańczyków. W ogóle, rozpatrując liczne pisma humorystyczne i takież kalendarze, dochodzi się do wniosku, iż ugrupowanie stańczyków przyniosło Polsce najwięcej szkód. Teksty różnych „krakowiaków", ballad, monologów i poematów antystańczykowskich zajęłyby objętość sporego tomu. Sprawę dziwacznych rozstrzygnięć konkursu na pomnik Mickiewicza, którą komentowano w całym kraju, Bartoszewicz wykpiwa w krótkim poemaciku wyszydzającym werdykt jury. Oto podsumowanie:

Takim sposobem ten konkurs odbyto,

Gujski i Rygier rwą włosy z rozpaczy,

Gadomski szlocha, Siemiradzki ditto,

Matejko przysiągł malować inaczéj,

Ozdobion bowiem tak potężnym sińcem

Dostrzegl, że w sztuce jest dziś barbarzyńcem ${ }^{68}$.

Ulubionym motywem humorystów były wybory do sejmu i rad miejskich oraz debaty nad sprawami publicznymi. Rozgrywały się one przez dłuższy czas. Dochodziło wówczas w nich do starcia różnych programów, postaw i osobowości, toteż o skojarzenia $z$ eposem bohaterskim było wyjątkowo łatwo ${ }^{69}$. Powagi publiczne, znani literaci,

${ }^{67}$ Ibidem, s. 56.

${ }^{68}$ K. Bartoszewicz, 40 kronik..., op. cit., s. 19.

${ }^{69}$ Por. Wlościanin z brzeskiego powiatu, Przed wyborami..., op. cit.; Maczuga [E. Eoziński], Z sanockiej ziemi, „Diabel” R. 17: 1885, nr 22, Dodatek, s. 1. Elementem degradującym przedmiot opowieści mogły być, obok stylu heroikomicznego, aluzje do niechlubnych wydarzeń historycznych. Zob. Wojna kokosza ( $z$ dziejów inteligencji krakowskiej), „Diabeł” R. 16: 1884, nr 4, s. 7: 
dziennikarze i reprezentanci świata akademickiego, którzy się włączali w czynne życie polityczne, a w ferworze polemik ujawniali zacietrzewienie, stronniczość poglądów czy zachowania nielicujące z powagą spraw publicznych, stawali się — jako bohaterowie tekstów humorystycznych - komicznie zdegradowani, mali i pospolici. Ośmieszona powaga dotyczyła głównie osób, które były powszechnie znane z manifestów, programów i wystąpień utrzymanych w stylu poważnym i wzniosłym: Stanisława Koźmiana $^{70}$, Tadeusza Romanowicza, Józefa Szujskiego, Stanisława Tarnowskiego. Spór w krakowskiej Radzie Miasta o przeznaczenie placu, który straszył resztkami dawnego kościoła Św. Ducha, był przez „Diabła” przedstawiony w rysunkowej karykaturze jako starcie uzbrojonych w kopie husarzy. Komentarz wierszowany wykorzystywał styl poematu bohaterskiego, łącząc go z potocznym, co zresztą było złym rozwiązaniem, gdyż wulgaryzmy osłabiały silę dowcipu satyrycznego:

I zaczął się bój srogi, aż trzaski leciały!

Pan Tarnowski rozpoczął, ale spotniał cały,

Lecz przez Romanowskiego gdzieś w łydkę dotknięty,

Usunął z placu boju rozmachane pięty. [...]

I nareszcie „Czas” się rzucil, ale już po walce,

I krzyczał na wsze strony: „Wandale! Padalce!”,

Plótl trzy po trzy — dopóki nie padł z wściekłą pianą!

Słychać, że do Pasteura tę pianę wysłano! ${ }^{71}$

W grupie takich utworów poziomem artystycznym wyróżnia się Ogniem i mieczem Bartoszewicza, poemat poświęcony starciu stańczyków ze stronnictwem demokratów w wyborach do Rady Miasta.

\footnotetext{
W Radzie miejskiej wrzaski, krzyki,

Oskarżenia i repliki,

Pan mecenas $\mathrm{z}$ akuszerem

Prezydenta zowią zerem.

Pełni werwy, pełni buty

Straszne czynią mu wyrzuty:

Że nie robi nic dla miasta [...].
}

${ }^{70}$ Nieraz można już mówić o paszkwilu, jak w poniższej trawestacji Ujejskiego wymierzonej w Koźmiana:

Z dymem gniazd naszych, z pianą ślin wściekłych,

Do Ciebie, Panie, bije ten głos;

Grzmi jęk z gardzieli rozpaczą spiekłych,

Ratuj, bo straszny dotknął nas cios!

(Do bożka Molocha. Chorat skomponowany przez Stasia K., „Diabel” R. 21: 1889, nr 14, s. 1).

${ }^{71}$ Walka stoczona $w$ radzie miejskiej o budynek S-go Ducha między zwolennikami teatru a stronnikami archeologów zbudzonych z snu siedmioletniego, „Diabeł” R. 20: 1888, nr 14, s. 8. 
Wojnę opiewam, jakiej od lat wiela

Ani widziało oko Izraela,

Ani toczyly pochopne do zgody,

Lechii narody. [...]

Nadszedł dzień straszny, gdy wedle ustawy

Miano wziąć starych rajców do naprawy,

To jest przewietrzyć, dezynfekcjonować,

Polakierować. [...]

Więc Adam Asnyk rozgrzał się okrutnie,

I potrząsając swym Kiejstutem butnie,

Zakuwszy ciało w zbroicę ze stali,

Po ziobrach wali.

Koźmian wziął srodze po tbie poematem,

Zollowi ucho oberwal dramatem,

Tarnowski, gdy się doń obrócil grzbietem,

Wziął w kark sonetem ${ }^{72}$.

Wydarzenia w średniej szkole rolniczej w podkrakowskim Czernichowie upamiętnił humorystycznym eposem ks. Mateusz Jeż. Miały podtekst polityczno-wychowawczy. Przed sprowadzeniem prochów Mickiewicza do Krakowa (1890) młodzież galicyjska rozwijała kult poety, urządzając wieczorki literackie, które równocześnie były hołdem składanym powstaniu listopadowemu. Starostwo krakowskie w roku 1888 wydało zarządzenie ograniczające udział uczniów w tych obchodach. W szkole w Czernichowie wieczór połączony z koncertem i żywymi obrazami odbył się spokojnie ${ }^{73}$, jednak 8 grudnia uczniowie zirytowani nadmiernym kontrolowaniem ich prywatności przez księdza-prefekta wybili mu szyby w oknach. Śledztwo doprowadziło do eskalacji wybryków - demolowano sale szkolne, obrzucono nauczycieli jajkami. Szkoła ta była początkowo przeznaczona dla kształcenia ekonomów i oficjalistów dworskich, od roku 1882 przekształcono ją w państwową szkołę średnią, co było dużym osiągnięciem organizacyjnym, dlatego omawiane wypadki uznano za bardzo poważne. Nie ma wątpliwości, że uczniowie złamali obowiązujący regulamin szkolny ${ }^{74}$.

${ }_{72}^{7 K}$. Bartoszewicz], Ogniem i mieczem. Powieść z ostatnich dni czenvca, op. cit., s. 3-4, 12-13.

73 Zob. [Kronika miejscowa i zagraniczna], „Czas” R. 41: 1888, nr 285, s. 3.

${ }^{74}$ Zob. Przepisy obowiazujace uczniów krajowej średniej Szkoty Rolniczej w Czernichowie, b. m. i r.; F. Stefczyk, Pogląd historyczny na rozwój szkoły rolniczej w Czernichowie, Kraków 1887; Krajowa Średnia Szkoła Rolnicza $w$ Czernichourie, Kraków 1894. Przebieg wypadków opisanych w poemacie zgadza się z relacją umieszczoną w „Czasie” (op. cit.). 
Wzorem stylistycznym autora jest tu Pan Tadeusz:

O roku ów! Pamiętny dotąd w Czernichowie,

Kto ciebie tamże widział, temu dotąd mrowie

Przelatuje po piętach. [...]

Pod względem strukturalnym poemat spełnia większość cech heroicomicum: inwokacja, narada bitewna, bitwa z użyciem nietypowych środków etc.

Młodzież widząc, że belfry są podszyci tchórzem,

Ustawila się w oknach rzędem nad podwórzem

Zakładowym. - Gdy oni zaczęli wychodzić,

Młodzież dalej jajami z góry na nich godzić.

Był to pomysł nie lada. Sztuka bicia jajem

Jest w innych szkołach mało znanym obyczajem!

Lecz młodzież czernichowska dobrze zna się na niej,

Bo też — co prawda - na wsi jaja kupi taniej.

Jest to broń niebezpieczna. Chociaż nie kaleczy,

Ale zostawia ślady blado-żółtej cieczy,

A jeśli jeszcze jaja nie są całkiem świeże,

To na widok tych śladów obrzydzenie bierze.

Mimo nocnych ciemności strzały były celne,

I zrobiły na belfrach wrażenie piekielne:

Obryzgani paskudnie do domu zmykają

I po drodze na uczniów srodze narzekają ${ }^{75}$.

Najdonioślejszym politycznie wydarzeniem, które opisano w dwóch obszernych poematach, była karczemna awantura krakowska dotycząca dyskutowanego na soborze dogmatu o nieomylności papieża. W latach 1870-1871 tak w Krakowie, jak i we Lwowie ogłoszono kilka broszur o tzw. ultramontanach i moderantach. „Tydzień" Kraszewskiego i „Przegląd Lwowski” ks. Edwarda Podolskiego, a także powolana specjalnie dla propagowania uchwał soboru „Warownia Krzyża” podnosiły temperaturę ideową sporów. Personifikacją poglądów antypapieskich stał się niemiecki ksiądz Döllinger, który nieomylność ograniczał do rozstrzygania dylematów podczas soboru. Część profesorów uniwersyteckich w Krakowie do akcji poparcia poglądów Döllingera włączyła studentów, proponując im podpisanie specjalnego adresu. Publikacje „Kraju” i „Czasu” w tej sprawie wzburzyły umysły do tego stopnia, że w mieście doszło do zamieszek równych niedawnej sprawie z Barbarą Ubryk (zamurowaną zakonni-

75 Z. Z. Miłkowski [M. Jeż?], Poustanie w Czernichowie. Historia szlachecka $w$ siedmiu pieśniach, Kraków 1895, s. 6, 13 
cą). Znany z oratorskiego talentu ksiądz Zygmunt Golian podczas kazań wygłaszanych w kościele św. Floriana na Kleparzu oskarżył o herezję studentów podpisujących adres. Między mieszczaństwem kleparskim a studentami doszło do bójki, którą zresztą łatwo przerwała policja. Stan wzburzenia trwał jednak kilka tygodni, gdyż wkrótce zmarł Karol Gilewski, inicjator adresu, a jak pierwsze wystąpienia zbiegły się w czasie z uroczystością św. Stanisława, tak ów zgon przypadł na czas Bożego Ciała ${ }^{76}$, toteż łatwo było o niekontrolowane rozruchy spoleczne. Echa wojny francusko-pruskiej i los Komuny Paryskiej byly smutną przestrogą przed konfliktami wewnętrznymi. Autorzy tych poematów, Anczyc i Bąkowski, starali się apelować o solidaryzm, choć nie ukrywali inspirującej roli księdza Goliana. Tak przedstawial go Anczyc:

Gdy głos potężny wzniesie na ambonie,

Drży wszelki kacerz i zdycha liberał,

Gdy na bezbożnych gniew srogi wyzionie,

Zda się, że wszystkich w proch by porozcierał.

A gazeciarzom gdy wlezie na skórę,

To już każdemu chyba w mysią dziurę.

Kończy zaś opis zawstydzeniem:

Żarty na stronę. O biedny narodzie!

$\mathrm{Na}$ toż ci przyszło, że zamiast żyć z sobą

W miłości bratniej i serdecznej zgodzie

Na biednej ziemi, okrytej żałobą -

Kiedy cię lada podjudzi człeczyna,

W bratobójczego zmieniasz się Kaina?!?7

Drugi z autorów, Bąkowski, wydał swój poemat w kilkanaście lat po wspomnianych wyżej wypadkach. Z treści wyraźnie widać, iż korzystał z publikacji w „Przeglądzie Lwowskim", w tym $z$ wersji samego Goliana. Nie usprawiedliwial księdza, ale prawdziwych inspiratorów widział w gronie studentów narodowości żydowskiej. Tak lud kleparski, jak studenci mają wlasnych przywódców, którzy odmiennie im rzecz naświetlają. Z perspektywy parafian księdza Goliana rzecz się ma następująco:

Ponoć stolicę Kościoła zamierza

Wróg zabrać, pragnie wypędzić papieża? [...]

Ej akademiki! Ej panowie młodzi,

${ }^{76}$ Jednostronne, ale bardzo dokładne sprawozdania z wypadków przynosi „Przegląd Lwowski” R. 1: 1871, z. 11-13. Por. też Do historii uypadków krakouskich w maju 1871 r., Lwów 1871.

${ }_{77}$ W. Anczyc, Döllingeriada, op. cit., s. 372, 383. 
U was to wszystko po glowie wam chodzi,

Niewiara u was skrzydla rozpościera,

$\mathrm{Z}$ ust bezbożnika, jakiegoś Girtlera.

Profesorowie plotą wam androny -

Mówił i o tym wczoraj ksiądz z ambony.

Studenci mają własne zdanie:

Nie wiem, koledzy, dokąd Kościół zmierza,

Gdy nieomylność przyjmuje papieża,

Atoli skutki już się okazały,

Nasz Padurowicz, Gilewski — wyklęci! ${ }^{78}$

Główna rola przypada w utworze staremu Mateuszowi, który jako weteran roku 1863 wzywa do jedności inteligencję i robotników. Utwór kończy się wyraźnymi akcentami antysemickimi - jedność narodowa, potwierdzona czynami Kościuszki i Poniatowskiego, ma być zagrożona wskutek wzrastającego znaczenia ekonomicznego ludności żydowskiej. Na ideę utworu, obok antysemityzmu, miała tė̇ wpływ potężniejąca fala propagandy socjalistycznej. Ideologia solidarności narodowej, potwierdzonej wydarzeniami z historii Polski, służłła autorowi do obrony przed wpływem haseł socjalistycznych.

Ważnym dowodem rozpaczy Polaków po klęsce Francji w wojnie z Prusami był poemat heroikomiczny Krystyna Ostrowskiego Napoleon XIII. Nie mial jednak sily oddziaływania społecznego, gdyż wydano go w Paryżu, toteż nie trafił do wielu czytelników. Jest to wierszowany żywot cesarza Napoleona III, przedstawiony jako pasmo nieustannych oszustw, zdrad, niedorzeczności politycznych, bezeceństw osobistych i pospolitej głupoty. Gdyby go przeczytał Ignacy Rzecki, to — jako oficer węgierskiej piechoty - pewnie zażądałby od autora satysfakcji... Bo, jak zapewniał autor, to:

Żywot zbrodniczy, piekielny,

Pełen żydowskiej obłudy,

I w tym tylko nieśmiertelny,

Że umiał oszukać ludy.

Więc, bracia dziejopisarze,

Przed Boga i Prawdy tronem,

Zwijmy go, z Judaszem w parze,

Trzynastym Napoleonem ${ }^{79}$.

${ }^{78}$ K. Bąkowski, Pan Mateusz czyli ostatni zajazd na Kleparzu..., op. cit., s. 9, 19.

${ }^{79}$ H. S. [K. Ostrowski], Napoleon XIII. Poemat heroikomiczny w dwudziestu pieśniach, op. cit., s. 3. 
Pozytywistyczny poemat humorystyczny, a zwłaszcza heroikomiczny, dotykał więc bardzo różnych problemów. Niewątpliwie zapisywal stan uczuć i umysłów, zwłaszcza społeczeństwa w Galicji. Wyraźnie podtrzymywał żywotność romantycznej tradycji literackiej zarówno poprzez cytaty i aluzje, jak też poprzez przedłużenie atrakcyjności gawędy i ramoty jako gatunku literackiego. Nawiązywał też do satyrycznych utworów Oświecenia i był bliski ideowo-tematycznemu kręgowi pozytywistycznej powieści tendencyjnej oraz satyrycznej. Można w nim znaleźć naprawdę zabawne i udane pomysły. Jako świadek czasów jest ciekawym dokumentem nastrojów społecznych. Żaden jednak utwór z tego kręgu nie przeżył swojej epoki. 